Research Article

\title{
Growth, Yield-Related Traits and Yield of Lowland Maize (Zea mays L.) Varieties as Influenced by Inorganic NPS and N Fertilizer Rates at Babile, Eastern Ethiopia
}

\author{
Mekuannet K. Belay (10 \\ School of Plant Sciences (Agronomy), Haramaya University, Haramaya, P.O. Box 138, Dire Dawa, Ethiopia \\ Correspondence should be addressed to Mekuannet K. Belay; belaym2012@gmail.com
}

Received 3 August 2020; Revised 17 November 2020; Accepted 21 November 2020; Published 16 December 2020

Academic Editor: Maria Serrano

Copyright (c) 2020 Mekuannet K. Belay. This is an open access article distributed under the Creative Commons Attribution License, which permits unrestricted use, distribution, and reproduction in any medium, provided the original work is properly cited.

\begin{abstract}
Appropriate selection of varieties based on agroecologies and application of the right amount and type of fertilizers based on crop requirements are crucially indispensable to maximize maize production. A field experiment was conducted for two consecutive years under main cropping seasons to evaluate the effect of blended NPS and N fertilizer rates on growth, yield components, and yield of open-pollinated maize varieties at the moisture stress area, eastern Ethiopia. The experiment was comprised of two lowland maize varieties, three blended NPS $(50,100$, and $150 \mathrm{~kg})$, and three N levels $(43.5,87$, and $130.5 \mathrm{~kg}) \mathrm{ha}^{-1}$ using a factorial arrangement under a randomized complete block design with three replications. The results showed that the leaf area index, thousand kernel weight, and biomass and grain yields were significantly influenced by the interaction effect of variety $\times$ NPS and N in the first growing season. The number of ears per plant, ear length, ear diameter, number of kernels per ear, and biomass yield were significantly affected due to variety in the second growing season. The maximum growth parameters and yield components were recorded from Baate and $150 \mathrm{~kg}$ blended NPS. Grain yield and harvest index were statistically affected by interaction effects of variety $\times$ NPS and N in both years. Therefore, the highest grain yield $\left(9.7 \mathrm{t} \cdot \mathrm{ha}^{-1}\right)$ was produced from Baate at a combined application of $150 \mathrm{~kg}$ NPS and $130.5 \mathrm{~kg} \mathrm{~N} \cdot \mathrm{ha}^{-1}$. The partial budget analysis also confirmed that the highest net benefit $(2,033.4$ USD) with the highest marginal rate of return (3106.9\%) was obtained at Baate variety where plants were fertilized with 150 NPS and $130.5 \mathrm{~kg} \mathrm{~N} \cdot \mathrm{ha}^{-1}$. In conclusion, an integrated application of $150 \mathrm{NPS}+130.5 \mathrm{~kg} \mathrm{~N} \cdot \mathrm{ha}^{-1}$ to Baate variety is agronomically optimum and economically realistic fertilizer level to get a higher grain yield in the study area.
\end{abstract}

\section{Introduction}

Maize (Zea mays L.) is one of the most important food crops worldwide and has the highest average yield per hectare among the cereals and it is grown in most parts of the world over a wide range of environmental conditions [1]. It is one of the most important cereal crops that allow the food selfsufficiency program of the country, playing a key role in the human diet and animal feed, providing adequate amounts of energy and protein [2]. In Ethiopia, more than 2.1 million hectares of land were covered with maize with a total production of nearly 8.4 million tons during the 2018 cropping season [3]. It accounted for about $16.80 \%$ out of $80.71 \%$ of the land allocated for all cereals. Maize is one of the major cereals grown next to sorghum in the mid- to highland areas of Eastern Hararghe which covered the total land area of 55,062.55 hectares and the main staple food following sorghum [3].

However, the average yield of Eastern Harargahe, in particular, and the national average yield, in general, are very low as compared to the average yield of developed countries due to various factors. Poor soil fertility is one of the bottlenecks for sustaining maize production and productivity in Ethiopia since most Ethiopian soils are a deficit in nutrients, especially nitrogen and phosphorus which are major yieldlimiting factors in maize potential production areas; as a result, our farmers have applied these nutrients for a long time in the form of DAP and urea as blanket 
recommendation [4]. However, the response of maize plants to the application of nitrogen and phosphorus fertilizers varies from variety to variety and location to location and also depends on the availability of the nutrients. Cultivars differ in their response to nutrient supply when planted in different geographical environments. Even application of these nutrients is not consistent by small-scale farmers due to an increasing cost of inorganic fertilizers and shifts in policies with respect to subsidizing fertilizer costs [5]. Therefore, nitrogen deficiency or excess can result in reducing maize yields and lack of phosphorus is also as important as the lack of nitrogen limiting maize performance [6]. Therefore, the application of appropriate rates and types of fertilizer is a crucial agronomic practice to maximize maize production. A field experiment conducted in western Ethiopia affirmed that biomass and grain yields were increased as NP fertilizer rates increased [7].

However, Ethiopian farmers used to apply only chemical fertilizers di-ammonium phosphate (DAP) and urea to increase crop yields for about five decades and this did not consider soil fertility status and crop requirement. Moreover, the soil fertility-mapping project in Ethiopia reported the deficiency of $\mathrm{K}, \mathrm{S}, \mathrm{Zn}, \mathrm{B}$, and $\mathrm{Cu}$ in addition to $\mathrm{N}$ and $\mathrm{P}$ in major Ethiopian soils and thus recommend the application of customized and balanced fertilizers [8]. Except the blanket recommendation of nitrogen and phosphorus, the effect of other fertilizers on yield components, yield, and overall performance of maize is also unknown, even though newly blended fertilizers such as NPS $\left(19 \% \mathrm{~N}, 38 \% \mathrm{P}_{2} \mathrm{O}_{5}\right.$, and $\left.7 \% \mathrm{~S}\right)$ are currently being used by the farmers in Ethiopia, including the study area. Many research findings confirmed that the application of NPS and $\mathrm{N}$ increased most growth parameters and yield components of maize [9-11]. For instance, the application of NPS + urea remarkably increased the grain yield of maize in West Gojjam of Ethiopia as compared to the blanket recommendation (DAP + urea) [12]. Sulfur is an essential nutrient for plant growth and development as it is a part of major metabolic compounds such as amino acids (methionine and cysteine), glutathione, proteins, and sulpholipids [13]. Other research findings also reported that blended fertilizers increased maize productivity compared to the previously existing NP [10]. Application of sulfur fertilizer increased the grain yield by $19.10 \%$ over no S application on an average basis, but further increase beyond $30 \mathrm{~kg}$ did not show increases in grain yields of maize, suggesting it as the optimum dose in the prevailing soil and plant conditions [14]. Thus, integrated nutrient application not only ensures the supply of essential nutrients to plants but also has some positive interactions to increase nutrient use efficiency and thereby reduce environmental hazards $[15,16]$, and appropriate selection of cultivars and optimum fertilizer rates are effective strategies to improve grain yield [17]. However, the farmers have applied $100 \mathrm{~kg}$ NPS with $150 \mathrm{~kg}$ urea ha ${ }^{-1}$ for all soil types and different maize (open and hybrid) varieties as blanket recommendation. Most research studies have been done on $\mathrm{N}$ and $\mathrm{P}$, but very few research works have been done on NPS to other crops. Therefore, this study was designed to determine the optimum rate of blended NPS and N for open-pollinated maize varieties to give better grain yield in the study area.

\section{Materials and Methods}

2.1. Site Description. The field experiment was conducted at Haramaya University Research Substation (Babile) for two consecutive years (2018/19 and 2019/20) under the main cropping season. The experimental site is located at $9013^{\prime}$ $13.5^{\prime \prime} \mathrm{N}$ latitude and $42019^{\prime} 20.9^{\prime \prime}$ E longitude and at an altitude of 1647 meters above sea level. The soil texture of the experimental site was dominantly sand. The mean annual maximum and minimum temperatures in the 2018 cropping season were 29.0 and $13.8^{\circ} \mathrm{C}$, respectively; similarly, the mean annual maximum and minimum temperatures were 28.8 and $13.9^{\circ} \mathrm{C}$, respectively, in 2019 . Total annual rainfall was 383.7 and $480.5 \mathrm{~mm}$ in the 2018 and 2019 cropping seasons, respectively (Table 1 ).

2.2. Description of Experimental Materials. The materials used in this study are shown in Table 2.

2.3. Experimentation. The field experiment was laid out under a randomized complete block design with a factorial arrangement with three replications. Factorial experimental treatments used in the study area were three blended NPS levels $\left(50,100\right.$, and $\left.150 \mathrm{~kg} \mathrm{ha}^{-1}\right)$, three $\mathrm{N}$ levels $(43.5,87$, and $\left.130.5 \mathrm{~kg} \mathrm{ha}^{-1}\right)$, and two open-pollinated maize varieties (Baate and Melkasa 2). Nitrogen was applied in the form of urea according to treatments. Depending on the nature of nutrients, full dose of blended NPS based on treatments was applied at sowing whereas nitrogen was applied in the split application $(1 / 2 \mathrm{~N}$ rate at sowing and the rest was applied 45 days after sowing). The nitrogen content in blended NPS is very low which is about $19 \mathrm{~kg} \mathrm{~N}$ out of $100 \mathrm{~kg}$ NPS not enough to plant growth and development, and thus, supplement $\mathrm{N}$ application is very essential to satisfy crop requirement.

2.4. Soil Sampling and Laboratory Analysis. It was done by taking one representative composite sample at a depth of 0-30 cm from five randomly selected spots diagonally across the experimental field using auger prior to sowing. The sample was dried at room temperature, thoroughly mixed, and ground to pass through a $2 \mathrm{~mm}$ sieve in preparation for laboratory analysis. The sample was analyzed for soil texture, $\mathrm{pH}$, organic carbon, total nitrogen, available phosphorus, and cation exchange capacity at Central Laboratory, Haramaya University, following the standard analytical procedures.

2.5. Data Collection. All data were collected following CIMMYT [19] guidelines as follows. Growth parameters were collected, and the leaf area index was recorded by taking a nondestructive sample of five plants from a net plot. Plant height $(\mathrm{cm})$ was determined by measuring the height of ten randomly sampled plants from ground level to the 
TABLE 1: Monthly maximum and minimum temperatures $\left({ }^{\circ} \mathrm{C}\right)$ and monthly total rainfall $(\mathrm{mm})$ at Babile during the 2018 and 2019 cropping seasons (Babile meteorological station).

\begin{tabular}{|c|c|c|c|c|c|c|}
\hline \multirow{4}{*}{ Months } & \multicolumn{4}{|c|}{ Cropping seasons } & \multirow{4}{*}{ Monthly total rainfall $(\mathrm{mm})$ in 2018} & \multirow{4}{*}{ Monthly total rainfall (mm) in 2019} \\
\hline & \multicolumn{2}{|c|}{2018} & \multicolumn{2}{|c|}{2019} & & \\
\hline & \multicolumn{4}{|c|}{ Mean $\left({ }^{\circ} \mathrm{C}\right)$} & & \\
\hline & Max temp. & Min. temp & Max temp. & Min. temp & & \\
\hline January & 29.2 & 14.7 & 29.6 & 16.2 & 0 & 0 \\
\hline February & 32.4 & 16.2 & 29.4 & 15.2 & 0 & 0 \\
\hline March & 28.4 & 13.6 & 29.2 & 13.2 & 3.5 & 3 \\
\hline April & 29.8 & 15.4 & 26.4 & 13 & 26 & 66 \\
\hline May & 27.2 & 13 & 28.1 & 13.3 & 89.2 & 131.5 \\
\hline June & 28.4 & 12.2 & 27.9 & 14.9 & 67 & 95.5 \\
\hline July & 27.4 & 13.2 & 28.4 & 12.2 & 61 & 21.5 \\
\hline August & 28.4 & 13.8 & 29.4 & 13 & 50 & 82 \\
\hline September & 30.2 & 14.4 & 28.4 & 15 & 55 & 6 \\
\hline October & 28.8 & 12.6 & 30 & 12 & 12 & 18 \\
\hline November & 29.2 & 12.2 & 20 & 30.4 & 15.2 & 57 \\
\hline Annual & 29.0 & 13.8 & 28.8 & 13.9 & 383.7 & 480.5 \\
\hline
\end{tabular}

TABLE 2: Experimental materials used in the study.

\begin{tabular}{|c|c|c|c|c|c|}
\hline \multirow{2}{*}{ Variety } & \multirow{2}{*}{ Year of release } & \multirow{2}{*}{ Altitude (m) } & \multirow{2}{*}{ Rainfall (mm) } & \multicolumn{2}{|c|}{ Yield potential (t/ha) } \\
\hline & & & & On research station & On farmers field \\
\hline MHQ138 & 2012 & NA & $1000-1800$ & $7.5-8.0$ & $5.5-6.5$ \\
\hline $\begin{array}{l}\text { BHQPY545 } \\
\text { Source: [18] }\end{array}$ & 2008 & $1000-1800$ & $1000-1200$ & $8.0-9.5$ & $5.5-6.5$ \\
\hline
\end{tabular}

$\mathrm{N}$ in the form of urea $100 \mathrm{~kg}$ urea $=46 \mathrm{~kg} \mathrm{~N}$

Fertilizers

Newly introduced blended NPS at $\left(19 \% \mathrm{~N}, 38 \% \mathrm{P}_{2} \mathrm{O}_{5}\right.$, and $\left.7 \% \mathrm{~S}\right) / 100 \mathrm{~kg}$ blended NPS different rates

base of the tassel at physiological maturity. Ear height $(\mathrm{cm})$ was recorded from ten randomly taken plants by measuring the height of the stem from ground level to the point of attachment of the uppermost ear at physiological maturity. Yield and yield components were also collected and the number of ears per plant was determined by counting the number of ears from the net plot area and divided by the stand count at harvest. Ear length $(\mathrm{cm})$ was determined from ten randomly selected ears per each net plot by measuring the ear from base to its tip at harvest. Ear diameter $(\mathrm{cm})$ was determined from ten randomly selected ears per each net plot by measuring the diameter of the ear. The number of kernels per ear was recorded by counting the number of kernels per ear from five randomly taken ears at harvest from the net plot. All plants found in each net plot area or three central rows were harvested and sundried for two days, and then their weight was recorded by using field weight balance. Thousand kernel weight (g): the number of kernels per ear was counted by using an electronic seed counter from a bulk of shelled grains per net plot and plants were weighed by using sensitive balance and the weight was adjusted at $12.5 \%$ moisture. Grain yield ( $\mathrm{t}$ $\mathrm{ha}^{-1}$ ):all ears were harvested from each net plot area and sun-dried and then weighted and multiplied by shelling percent (0.8), and the weight was adjusted to $12.5 \%$ by using a grain moisture tester. Then, the grain yield was converted to ton $\mathrm{ha}^{-1}$. Harvest index (\%) was calculated as the ratio of grain yield per net plot to the aboveground dry biomass per net plot at harvest from the respective treatments.

2.6. Data Analysis. Analysis of variance was run for growth, yield components, and yield of maize data using general linear model (GLM) to see whether treatments and their interactions are statistically significant or not. Analysis of variance was conducted using statistical software of GenStat 17 th ed. [20]. When ANOVA showed a significant treatment effect, mean separation was done using the least significant difference (LSD) test at the 0.05 probability level. $F$ test was also done to test homogeneity variances of both years' data according to Gomez and Gomez [21]. Based on $F$ test results, almost all data were inconsistent in both seasons. Therefore, both years' data were separately discussed.

2.7. Partial Budget Analysis. The partial budget analysis was carried out by using the methodology described in CIMMYT [22] in which prevailing market prices for inputs at sowing and outputs at harvesting were used. All costs and benefits were calculated on a hectare basis in birr. The mean grain yields were adjusted down by subtracting $10 \%$ to 
approach the real production conditions. Total variable costs were calculated as cost of fertilizers $(100 \mathrm{~kg}$ blended NPS/800 birr $+100 \mathrm{~kg}$ Urea/750 birr) plus fertilizer application costs (150 birr/man-day). The current open market price of $100 \mathrm{~kg}$ maize grain yield was $800 \mathrm{ETB}$, and the mean grain yield of each treatment was calculated. The net benefit (NB) was obtained by subtracting total variable costs from the gross benefit. In addition, the marginal rate of return was also calculated as a change in net benefit/ change in total variable cost $\times 100$. For a treatment to be considered as worthwhile to farmers, with the highest net benefit and marginal rate of return $>100 \%$ was considered for the recommendation.

\section{Results and Discussion}

3.1. Selected Physical and Chemical Properties of Soil. Soil sample and laboratory analysis indicated that the soil textures of the experimental site were dominantly sand. According to Murphy [23], rating in Table 3 indicated that total $\mathrm{N}$ content is low.

\subsection{Effect of Blended NPS and N Fertilizer Rates on Growth Parameters}

3.2.1. Leaf Area Index. The interaction effect of variety by NPS and $\mathrm{N}$ had a significant effect on the leaf area index in the first growing season. Mean values of leaf area index in Table 4 revealed that the maximum leaf area index was obtained at a treatment combination of $150 \mathrm{~kg}$ NPS and $130.5 \mathrm{~kg}$ N. Similarly, Melkasa 2 also gave the maximum leaf area index where plots were treated with $100 \mathrm{NPS}+130.5 \mathrm{~kg}$. The application of ample plant nutrients are important to promote the formation of chlorophyll which in turn resulted in higher photosynthetic activity, vigorous vegetative growth, and taller plants that attribute to produce more number of leaves per plant [27]. In addition, $\mathrm{P}$ is also important for shoot and root development that facilitates metabolism and cell division. Geremew [28] also reported that increasing $\mathrm{P}$ rates consistently increased the leaf area index of maize. Similarly, Sisay and Adugnaw [29] reported that leaf area index of maize increased as blended NPS increased.

Nevertheless, Baate variety produced the maximum leaf area index as compared to Melkasa 2 almost in all treatment combinations. Apart from fertilizer treatment variations, this leaf area index discrepancy might be occurred due to the existence of genetic variation between two varieties. As it was observed during data collection Baate variety was taller in plant height and had a large leaf size, even two varieties were treated with the same fertilizer rate; therefore, leaf area index could be governed by the number of leaves per plant and leaf areas. In case of a Baate variety, as $\mathrm{N}$ rate increased from 43.5 to $130.5 \mathrm{~kg}$ when NPS kept constant (50 kg NPS), the leaf area index was linearly increased, but other treatments were not linearly increased. On the contrary, Melkasa 2 gave the minimum leaf area index from an integrated application of $100 \mathrm{NPS}$ and $43.5 \mathrm{~N} \mathrm{~kg} \mathrm{ha}^{-1}$.
On the other hand, in the second year, a significant variation of leaf area index was observed due to variety and a significantly higher leaf area index was recorded from Baate over Melkasa 2 (Table 5). This is probably due to the presence of a high leaf area along with more number of leaves per plant in Baate variety that may contribute to a higher leaf area index. However, the leaf area index was not significantly responded to different fertilizer combinations within treatments.

3.2.2. Plant and Ear Heights $(\mathrm{cm})$. The mean values of plant and ear heights were not consistent across two growing years due to the variation of the interaction of genotypes by years. Therefore, a significant discrepancy was observed between two maize varieties in both years. The variation between two growing years for the measured traits is anticipated because the two growing seasons have different rainfall conditions. Mean values described in Table 5 indicated that taller plant $(164.9 \mathrm{~cm})$ and ear $(70.29 \mathrm{~cm})$ heights were found from Baate variety whereas shorter plant and ear heights were found from Melkasa 2 in the first growing season. Melkasa 2 variety is shorter by $5.2 \%$ over Baate variety. Similarly, in the second growing season, Baate variety gave higher plant and ear heights as compared to Melkasa 2. In both years, Baate variety gave higher plant and ear heights as compared to Melkasa 2. This clearly showed that the result of variation in the plant and ear heights might be due to the existence of genetic variation for these traits along with distinct rainfall amounts in growing seasons. Similar results were reported in [30-32] which showed that plant height was significantly affected by varieties; the tallest plant height was obtained from variety $\mathrm{BH}-661$ as compared to $\mathrm{BH}-543$. Additionally, other research findings investigated that KSC 604 maize variety gave higher plant height as compared to KSC 601 [33].

\subsection{Effect of Blended NPS and N Fertilizer Rates on Yield and Yield Components}

3.3.1. Number of Ears per Plant. The statistical analysis of variance showed that there was no significant difference in the number of ears per plant due to varieties and fertilizer treatments in the first cropping season but only significantly affected by the variety in the second cropping season. The mean values of the number of ears per plant in Table 6 depicted that Baate variety produced $14.3 \%$ more number of ears per plant over Melkasa 2. This could be due to the presence of genetic variation between the two varieties. Khaliq et al. [34] described that the number of ears per plant is governed by genetic character but not highly influenced by plant nutrition.

In the first cropping season, the weather data shown in Table 1 indicated that there was moisture stress at the flowering stage; as a result, both varieties produced the minimum number of ears per plant. Lack of moisture stress at the flowering stage causes a reduction of pollen viability and stickiness of stigma, and as a result, the grain yield drastically reduced. Relatively, in the second 
TABLE 3: Soil physical and chemical properties of the experimental site.

\begin{tabular}{lccc}
\hline Soil properties & Value & Rating & References \\
\hline Sand (\%) & 62 & & \\
Silt (\%) & 21 & & \\
Clay (\%) & 17 & & \\
Textural class & Sand & & \\
pH $(1: 2.5$ soil/water) & 8.92 & Strongly alkaline & {$[24]$} \\
Available P (ppm) & 15.51 & Moderate & {$[25]$} \\
OM (\%) & 4.6 & Medium & {$[24]$} \\
Total N (\%) & 0.11 & Low & {$[23]$} \\
CEC (meq/100g soil) & 26.88 & High & {$[26]$} \\
\hline
\end{tabular}

TABLE 4: Mean values of leaf area index as affected by interaction effect of variety $\times$ NPS $\times N$ in the 2018 cropping season.

\begin{tabular}{lcccc}
\hline & \multicolumn{3}{c}{ Treatments } & \multicolumn{2}{c}{$\mathrm{N}$ rate $\left(\mathrm{kg} \mathrm{ha}^{-1}\right)$} \\
Variety & NPS rate & 43.5 & 87 & 130.5 \\
\hline \multirow{3}{*}{ Baate } & 50 & $1.82^{\text {ghi }}$ & $2.28^{\text {cdefg }}$ & $2.39^{\text {bcdef }}$ \\
& 100 & $2.91^{\text {ab }}$ & $2.76^{\text {abc }}$ & $2.64^{\text {abcd }}$ \\
& 150 & $2.66^{\text {abcd }}$ & $2.53^{\text {abcde }}$ & $2.96^{\text {a }}$ \\
Melkasa 2 & 50 & $1.97^{\text {fghi }}$ & $1.73^{\text {hi }}$ & $2.03^{\text {efghi }}$ \\
& 100 & $1.65^{\mathrm{i}}$ & $2.18^{\text {defgh }}$ & $2.33^{\text {cdefg }}$ \\
LSD $(0.05)=0.52$ & 150 & $2.07^{\text {efghi }}$ & $2.04^{\text {efghi }}$ & $2.12^{\text {efghi }}$ \\
CV $(\%)=13.8$ & & & & \\
\hline
\end{tabular}

Means in the table following the same letter (s) are not statistically significant at the 0.05 probability level. LSD = least significant difference; $\mathrm{CV}=$ coefficient of variation

cropping season, high rainfall in amount and regular distribution was recorded which had a positive effect on yield components and yield of two open-pollinated maize varieties. However, in most parameters, Baate variety was superior to Melkasa 2 in both seasons. This is probably due to genetic variation existed between two varieties. Similarly, Khan et al. [17] reported that a significant variation was observed on the number of ears per plant due to varieties. Belay and Adare [9] also affirmed that various numbers of ears per plant were recorded from two hybrid maize varieties.

3.3.2. Ear Length and Diameter $(\mathrm{cm})$. Statistical analysis of variance showed that a significant variation of ear length was observed due to variety in 2019. Relatively, both varieties produced a longer ear length in the second cropping season as compared to the first cropping season. On the other hand, ear length produced from Baate variety was increased by $10 \%$ as compared to Melkasa 2 in the second cropping season (Table 6). Variation of ear length within a season between two varieties indicated that there is a genetic difference between two maize varieties. However, both varieties produced different ear lengths at both seasons. This is probably due to the inconsistency of weather data in both seasons. The result is in line with Ahmad et al. [35] who reported that ear length was significantly influenced due to varieties. This result is also supported by Anjorin and Ogunniyan [36].
TABle 5: Mean values of leaf area index, plant height, and ear heights as affected by the main effect of variety in the 2018 and 2019 cropping seasons.

\begin{tabular}{lcccccc}
\hline \multirow{2}{*}{ Variety } & \multicolumn{2}{c}{$\begin{array}{c}\text { Leaf area } \\
\text { index }\end{array}$} & \multicolumn{2}{c}{$\begin{array}{c}\text { Plant height } \\
(\mathrm{cm})\end{array}$} & \multicolumn{2}{c}{$\begin{array}{c}\text { Ear height } \\
(\mathrm{cm})\end{array}$} \\
& 2018 & 2019 & 2018 & 2019 & 2018 & 2019 \\
\hline Baate & $2.6^{\mathrm{a}}$ & $2.9^{\mathrm{a}}$ & $164.9^{\mathrm{a}}$ & $164.2^{\mathrm{a}}$ & $70.29^{\mathrm{a}}$ & $70^{\mathrm{a}}$ \\
Melkasa 2 & $2.0^{\mathrm{b}}$ & $2.2^{\mathrm{b}}$ & $156.3^{\mathrm{b}}$ & $150.8^{\mathrm{b}}$ & $62.11^{\mathrm{b}}$ & $59.9^{\mathrm{b}}$ \\
\hline LSD (0.05) & 0.17 & 0.16 & 5.0 & 4.1 & 3.7 & 3.45 \\
CV (\%) & 13.8 & 11.2 & 5.6 & 4.7 & 10.0 & 9.6 \\
\hline
\end{tabular}

Means in the columns following the same letter are not statistically significant at the 0.05 probability level. LSD = least significant difference; $\mathrm{CV}=$ coefficient of variation.

TABLE 6: The number of ears per plant, ear length, and ear diameter as affected by the main effect of variety in the 2018 and 2019 cropping seasons.

\begin{tabular}{lcccc}
\hline & $\begin{array}{c}\text { Number of ears per } \\
\text { plant }\end{array}$ & Ear length $(\mathrm{cm})$ & \multicolumn{2}{c}{$\begin{array}{c}\text { Ear } \\
\text { diameter } \\
(\mathrm{cm})\end{array}$} \\
\hline Variety & 2019 & 2019 & 2018 & 2019 \\
\hline Baate & $1.4^{\mathrm{a}}$ & $16.3^{\mathrm{a}}$ & $4.4^{\mathrm{a}}$ & $3.2^{\mathrm{a}}$ \\
Melkasa 2 & $1.2^{\mathrm{b}}$ & $15.2^{\mathrm{b}}$ & $4.2^{\mathrm{b}}$ & $3.0^{\mathrm{b}}$ \\
\hline LSD (0.05) & 0.1 & 0.61 & 0.1 & 0.1 \\
CV (\%) & 14.5 & 7.1 & 4.0 & 6.9 \\
\hline
\end{tabular}

Means in the columns following the same letter are not statistically significant at the 0.05 probability level. $\mathrm{LSD}=$ least significant difference; $\mathrm{CV}=$ coefficient of variation.

The other essential yield component ear diameter was significantly affected by the variety in both seasons. Therefore, thicker ear diameter was produced in the first growing season as compared to the second growing season. However, there was also a varietal difference, and nearly $4.5 \%$ thicker ear diameters were produced from Baate variety as compared to Melkasa 2 in both seasons. The thicker ear diameter in Baate variety could have resulted in large kernel sizes. Similarly, Hamidi and Nasab [33] reported that KSC 604 maize hybrid produced longer ear length and thicker ear diameter than KSC 601.

3.3.3. Number of Kernels per Ear. There was a significant variation in the number of kernels per ear due to a variety in both seasons, but other treatments were nonsignificant. In both seasons, Baate variety produced a higher number of kernels per ear whereas Melkasa 2 produced a lower number of kernels per ear in the second cropping season (Table 7). The number of kernels per ear produced from Baate was increased by 8.1 and $16.9 \%$ over Melkasa 2 in the first cropping season and in the second cropping seasons, respectively. The maximum number of ears per plant, thick ear diameter, and longer ear length were produced by Baate variety. Therefore, having longer ear lengths along with thicker ear diameter had a direct contribution to produce the highest number of kernels per ear for Baate variety. Maize variety having thicker ear diameter (more number of rows 
TABLE 7: Mean values of the number of kernels per ear, thousand kernel weight, and biomass yield as influenced by the main effect of variety in both seasons.

\begin{tabular}{lcccr}
\hline Variety & \multicolumn{2}{c}{ Number of kernels per ear } & \multicolumn{2}{c}{$\begin{array}{c}\text { Biomass yield } \\
\left(\mathrm{kg} \mathrm{ha}^{-1}\right)\end{array}$} \\
\hline Baate & 2018 & 2019 & 2018 & 2019 \\
Melkasa 2 & $520.0^{\mathrm{a}}$ & $543.7^{\mathrm{a}}$ & $10.2^{\mathrm{a}}$ & $15.8^{\mathrm{a}}$ \\
\hline LSD (0.05) & $477.6^{\mathrm{b}}$ & $451.9^{\mathrm{b}}$ & $8.1^{\mathrm{b}}$ & $12.4^{\mathrm{b}}$ \\
CV (\%) & 26.50 & 23.99 & 0.71 & 1.2 \\
\hline
\end{tabular}

Means in the columns following the same letter are not statistically significant at the 0.05 probability level. $\mathrm{LSD}=$ least significant difference; $\mathrm{CV}=$ coefficient of variation.

per ear) and longer ear length (more number of kernels per row) could produce more number of kernels per ear because number of kernels per ear is the result of number of rows per ear $\mathrm{x}$ number of kernels per row. The result is in accordance with $[37,38]$ which reported that the number of kernels per ear was significantly affected by variety. Hejazi and Soleyman [39] also stated that a significant variation in the number of kernels per ear was observed due to varieties.

3.3.4. Thousand Kernel Weight (g). Statistical data analysis of variance indicated that three-way interaction of variety $\times \mathrm{NPS} \times \mathrm{N}$ had a significant effect on thousand kernel weight in the first cropping season. The combined application of $150 \mathrm{NPS}$ and $87 \mathrm{~kg} \mathrm{~N} \mathrm{ha}^{-1}$ to Baate variety gave considerably higher thousand kernel weight as compared to other treatments. This clearly showed that the application of $150 \mathrm{~kg}$ NPS by $87 \mathrm{~kg}$ $\mathrm{N}$ increased the thousand kernel weight by $24.7 \%$ over the existing recommendations (100 NPS $\times 87 \mathrm{~N})$. However, the lowest thousand kernel weight was noted from Melkasa 2 where plots were treated with $100 \mathrm{~kg}$ NPS with $130.5 \mathrm{~kg} \mathrm{~N} \mathrm{ha}^{-1}$ (Table 8). This result is in line with Abera and Adinew [40] who found that the maximum thousand kernel weight was obtained from late maturing hybrid maize variety where plants were fertilized with $200 \mathrm{~kg}$ NPS and $92 \mathrm{~kg} \mathrm{~N}$ in southern Ethiopia. Likewise, Fareed [41] and Hussain et al. [42] observed an increase in 1000-grain weight with an increase in NP application. Ahmad et al. [35] also reported that 1000-grain weights were significantly affected by the interaction effect of variety by nitrogen. Similar findings were also reported by Khan et al. [17]. This clearly showed that the application of $150 \mathrm{~kg}$ NPS with $87 \mathrm{~kg} \mathrm{~N}$ could be optimum growth resource to assimilate more photosynthates to properly fill the kernels. On the other hand, the presence of adequate $\mathrm{N}$ and $\mathrm{S}$ nutrients within the plant tissue plays a great role in biochemical processes, which contributed to more photosynthetic activities and thus resulted in the production of optimum assimilate for subsequent translocation to the plant parts for economic grain yield [43]. Besides, an increase in 1000-grain weight might be due to enhancement in source efficiency as well as sink capacity [44]. In most cases, plots treated with the lowest fertilizer rates produced more thousand kernel weight as compared to plots treated with the highest fertilizer levels in the first growing season. When a plant was challenged with moisture stress at a reproductive stage, plots that were treated with the highest fertilizer levels might be enforced to maturity before its maturity time, and as a result, the kernels did not fill properly with photosynthates. This could be
TABLE 8: Mean values of thousand kernel weight as influenced by the interaction of variety by NPS and N in the 2018 cropping season.

\begin{tabular}{lcccc}
\hline & Treatments & \multicolumn{3}{c}{$\mathrm{N}$ rate $\left(\mathrm{kg} \mathrm{ha}^{-1}\right)$} \\
Variety & NPS rate $\left(\mathrm{kg} \mathrm{ha}^{-1}\right)$ & $43.5^{\mathrm{bcd}}$ & 87 & 130.5 \\
\hline \multirow{3}{*}{ Baate } & 50 & $213.1^{\mathrm{bcd}}$ & $199.5^{\mathrm{d}}$ & $199.9^{\mathrm{d}}$ \\
& 100 & $248.8^{\mathrm{bcd}}$ & $250.7^{\mathrm{bcd}}$ & $236.9^{\mathrm{bcd}}$ \\
& 150 & $206.9^{\mathrm{cd}}$ & $338.3^{\mathrm{a}}$ & $197.7^{\mathrm{d}}$ \\
Melkasa 2 & 50 & $252.7^{\mathrm{bcd}}$ & $210.7^{\mathrm{cd}}$ & $224.7^{\mathrm{bcd}}$ \\
& 100 & $246.2^{\mathrm{bcd}}$ & $268.3^{\mathrm{b}}$ & $196.1^{\mathrm{d}}$ \\
& 150 & $261.4^{\mathrm{bc}}$ & $208.9^{\mathrm{cd}}$ & $217.1^{\mathrm{bcd}}$ \\
\hline
\end{tabular}

$\operatorname{LSD}(0.05)=57.39$

$\mathrm{CV}(\%)=14.9$

Means in the table following the same letter are not statistically significant at the 0.05 probability level. $\mathrm{LSD}=$ least significant difference; $\mathrm{CV}=$ coefficient of variation.

one of the factors for reducing thousand kernel weight at the highest fertilizer levels under moisture stress. On the other hand, in the second cropping season, thousand kernel weight was not significantly affected by both varieties and fertilizer treatments.

3.3.5. Aboveground Biomass Yield $\left(t h a^{-1}\right)$. Statistically, a significant variation was observed in aboveground biomass yield due to three-way interactions of variety by NPS and N in the first cropping season. The combined application of $150 \mathrm{~kg}$ NPS with $87 \mathrm{~kg} \mathrm{~N} \mathrm{ha}^{-1}$ to Baate variety increased aboveground biomass yield by $51.1 \%$ over Melkasa 2 which received $50 \mathrm{~kg}$ NPS $+43.5 \mathrm{~kg} \mathrm{~N}$ (Table 9). In the case of Baate at 50 and $100 \mathrm{~kg}$ NPS, aboveground biomass yield increased as nitrogen rate increased from 43.5 to $130.5 \mathrm{~kg} \mathrm{~N}$, but at $150 \mathrm{~kg}$ NPS level, it was increased up to $87 \mathrm{~kg} \mathrm{~N}$ and then declined. This implied that the addition of extra nitrogen beyond $87 \mathrm{~kg} \mathrm{~N}$ at a combination of $150 \mathrm{~kg}$ NPS is uneconomical because biomass yield was not responded. In addition, the content of $\mathrm{N}$ increased as NPS increased. Therefore, at Babile soil, the application of integrated $150 \mathrm{~kg}$ NPS $+87 \mathrm{~kg} \mathrm{~N} \mathrm{ha}^{-1}$ gave the adequate fertilizer rate under the weather condition indicated in Table 1 . On the other way, in case of Melkasa 2 variety, aboveground biomass yield increased as nitrogen fertilizer rate increased from 43.5 to $87 \mathrm{~kg} \mathrm{~N}$ at each NPS level and then declined. Normally, the responses of varieties to applied fertilizer are varied, and this is basically observed between two experimental materials used in the study. Similarly, it has been found that aboveground biomass yields varied across hybrid maize varieties 
TABLE 9: Mean values of aboveground biomass yield as affected by the interaction effect of variety $\times$ NPS $\times$ N in the 2018 cropping season.

\begin{tabular}{|c|c|c|c|c|}
\hline \multirow{2}{*}{ Variety } & \multirow{2}{*}{ NPS rate $\left(\mathrm{kg} \mathrm{ha}^{-1}\right)$} & \multicolumn{3}{|c|}{$\mathrm{N}$ rate $\left(\mathrm{kg} \mathrm{ha}^{-1}\right)$} \\
\hline & & 43.5 & 87 & 130.5 \\
\hline \multirow{3}{*}{ Baate } & 50 & $8.4^{\mathrm{ef}}$ & $8.4^{\mathrm{def}}$ & $9.2^{\text {cde }}$ \\
\hline & 100 & $10.5^{\mathrm{bc}}$ & $10.6^{\mathrm{bcd}}$ & $12.6^{\mathrm{ab}}$ \\
\hline & 150 & $9.3^{\text {cde }}$ & $13.5^{\mathrm{a}}$ & $8.8^{\text {cde }}$ \\
\hline \multirow{3}{*}{ Melkasa 2} & 50 & $6.6^{\mathrm{f}}$ & $9.0^{\text {cde }}$ & $8.3^{\text {ef }}$ \\
\hline & 100 & $8.3^{\text {ef }}$ & $8.3^{\mathrm{ef}}$ & $7.7^{\mathrm{ef}}$ \\
\hline & 150 & $8.2^{\text {ef }}$ & $7.6^{\mathrm{ef}}$ & $8.9^{\text {cde }}$ \\
\hline
\end{tabular}

LSD $(0.05)=2.13$

$\mathrm{CV}(\%)=14$

Means in the table following the same letter are not statistically significant at the 0.05 probability level. $\mathrm{LSD}=$ least significant difference; $\mathrm{CV}=$ coefficient of variation.

and $\mathrm{N}$ treatments in the 2013 and 2014 cropping seasons [13].

On the other hand, in the second cropping season, significantly higher biomass yield was obtained due to variety and NPS. Therefore, Baate variety produced $21.5 \%$ more aboveground biomass yield as compared to Melkasa 2. This is probably due to the presence of thick stalks, taller plant height, and more grain yield that may attribute to have higher biomass yield for Baate variety. On the other hand, as the blended NPS rate increased from 50 to $150 \mathrm{~kg}$, aboveground biomass yield was linearly increased from 13.15 to $15.31 \mathrm{t} \mathrm{ha}^{-1}$. Therefore, the addition of $150 \mathrm{~kg}$ NPS to the soil had a $14.1 \%$ more biomass yield advantage than the application of $50 \mathrm{~kg}$ NPS. The significant variations were not observed between 50 and $100 \mathrm{~kg}$ NPS as well as 100 and $150 \mathrm{~kg}$ NPS; nevertheless, there was a statistical difference between the application of $50 \mathrm{~kg}$ and $150 \mathrm{~kg}$ NPS. Therefore, the soil sample laboratory analysis results showed that the availability of phosphorus and total nitrogen contents was moderate and low, respectively (Table 3 ), resulting in plants that are more responsive to the highest NPS level. Overall, the application of $150 \mathrm{~kg}$ NPS ha ${ }^{-1}$ gave the highest aboveground biomass yield in both seasons. This result was in line with Bakht et al. [45] who reported that the maximum number of leaves plant ${ }^{-1}$, number of cobs plant, number of grains cob, taller plants, grain, and the biological yield were recorded in the application of $200 \mathrm{~kg} \mathrm{~N} \mathrm{ha}^{-1}$. Similarly, Ahmad et al. [35] also confirmed that the effect of nitrogen levels and cultivars was significant in biological yield.

3.3.6. Grain Yield $\left(t h a^{-1}\right)$. Grain yield was highly $(P<0.01)$ affected by three-way interactions of variety by NPS and N in both seasons. As indicated in Table 10, the maximum mean value of grain yield $\left(3.9 \mathrm{t} \mathrm{ha}^{-1}\right)$ was obtained from Baate variety where plots were treated with $150 \mathrm{~kg}$ NPS and $87 \mathrm{~N}$ $\mathrm{ha}^{-1}$ whereas minimum grain yield $\left(2.6 \mathrm{t} \mathrm{ha}^{-} 1\right)$ was obtained from Melkasa 2 where plots were treated with $50 \mathrm{~kg}$ NPS with $43.5 \mathrm{~kg} \mathrm{~N}$ (Table 9) in the first growing season. On the other hand, Baate variety gave the lowest grain yield at the highest treatment combination of $150 \mathrm{~kg}$ NPS with $130.5 \mathrm{~kg}$ $\mathrm{N}$ in the same season. This is because plots fertilized with the highest combined application rate $(150 \mathrm{~kg}$ NPS with $130.5 \mathrm{~kg}$ $\mathrm{ha}^{-1}$ ) were hasten to days to maturity since the extent of salt
TABLE 10: Mean values of grain yield as affected by the interaction effect of variety $\times$ NPS $\times N$ in the 2018 and 2019 cropping seasons.

\begin{tabular}{|c|c|c|c|c|}
\hline \multirow[b]{2}{*}{ Variety } & \multicolumn{2}{|l|}{ Treatments } & \multicolumn{2}{|c|}{$\begin{array}{l}\text { Grain yield } \\
\left(\mathrm{t} \mathrm{ha}^{-1}\right)\end{array}$} \\
\hline & NPS rate $\left(\mathrm{kg} \mathrm{ha}^{-1}\right)$ & $\mathrm{N}$ rate $\left(\mathrm{kg} \mathrm{ha}^{-1}\right)$ & 2018 & 2019 \\
\hline \multirow{9}{*}{ Baate } & \multirow[t]{3}{*}{ 为 } & 43.5 & $3.0^{\text {bcde }}$ & $6.5^{\mathrm{bc}}$ \\
\hline & & 87 & $2.8^{\mathrm{de}}$ & $6.2^{\mathrm{bcd}}$ \\
\hline & & 130.5 & $3.1^{\mathrm{abcde}}$ & $6.5^{\mathrm{bc}}$ \\
\hline & \multirow{3}{*}{100} & 43.5 & $3.5^{\mathrm{abcd}}$ & $6.3^{\mathrm{bcd}}$ \\
\hline & & 87 & $3.2^{\text {abcde }}$ & $7.7^{\mathrm{b}}$ \\
\hline & & 130.5 & $3.7^{\mathrm{abc}}$ & $6.6^{\mathrm{bc}}$ \\
\hline & \multirow{3}{*}{150} & 43.5 & $2.9^{\text {cde }}$ & $5.0^{\mathrm{cd}}$ \\
\hline & & 87 & $3.9^{\mathrm{a}}$ & $6.6^{\mathrm{bc}}$ \\
\hline & & 130.5 & $2.8^{\mathrm{de}}$ & $9.7^{\mathrm{a}}$ \\
\hline \multirow{9}{*}{ Melkasa 2} & \multirow{3}{*}{50} & 43.5 & $2.6^{\mathrm{e}}$ & $4.6^{\mathrm{d}}$ \\
\hline & & 87 & $3.8^{\mathrm{ab}}$ & $5.7^{\mathrm{cd}}$ \\
\hline & & 130.5 & $3.2^{\text {abcde }}$ & $5.0^{\mathrm{cd}}$ \\
\hline & \multirow{3}{*}{100} & 43.5 & $3.2^{\text {abcde }}$ & $5.4^{\mathrm{cd}}$ \\
\hline & & 87 & $3.5^{\mathrm{abcd}}$ & $5.3^{\mathrm{cd}}$ \\
\hline & & 130.5 & $3.5^{\mathrm{abcd}}$ & $5.1^{\mathrm{cd}}$ \\
\hline & \multirow{3}{*}{150} & 43.5 & $3.3^{\text {abcde }}$ & $5.8^{\mathrm{cd}}$ \\
\hline & & 87 & $2.7^{\mathrm{de}}$ & $5.2^{\mathrm{cd}}$ \\
\hline & & 130.5 & $3.4^{\text {abcde }}$ & $5.7^{\mathrm{cd}}$ \\
\hline LSD (0.05) & & & 0.86 & 1.65 \\
\hline $\mathrm{CV}(\%)$ & & & 15.9 & 16.4 \\
\hline
\end{tabular}

Means in the columns following the same letter are not statistically significant at the 0.05 probability level. LSD = least significant difference; $\mathrm{CV}=$ coefficient of variation.

(fertilizer) compared to other lower combination of fertilizer rates is high and devastating soil moisture stress. The delayed days to maturity was recorded where plots were treated with no fertilizer or at control. Therefore, at the highest fertilizer combination rate, the kernels were not duly filled with carbohydrates due to less kernels filling period due to moisture stress, and as a result, thousand kernel weight could be reduced. Overall, most of the yield components were reduced in the 2018 cropping season; as a result, the grain yield was dramatically decreased since yield is a cumulative effect of growth and yield components.

In the second cropping season, the application of a combined $150 \mathrm{~kg}$ NPS with $130.5 \mathrm{~kg} \mathrm{~N}$ fertilizer rates to Baate variety gave the highest grain yield $\left(9.7 \mathrm{t} \mathrm{ha}^{-1}\right)$ as compared to other treatments. However, the lowest grain yield $\left(4.6 \mathrm{t} \mathrm{ha}^{-1}\right)$ was obtained from Melkasa 2 variety where 
plots received the lowest fertilizer combination rates. The highest grain yield at the highest combination fertilizer rates might be due to the fact that when plants were fertilized with ample nutrients, plants can be vigorous, and good root and shoot development could be greatly contributed for maximizing photosynthetic rates which leads to a higher partitioning of assimilates to the economic portion and results in higher thousand kernel weight and grain yield. Similarly, Qahar and B. Ahmad [13] found that grain yield of maize was highly influenced by variety, nitrogen, and years. References $[7,11]$ reported that the highest grain yield was found at the highest application of P and N. Sharifi and Taghizadeh [30] also reported that the highest grain yield was obtained at the highest nitrogen level. Khalil et al. [46] reported that nitrogen and phosphorus alone or in combination significantly increased grain yield. Similar results were obtained in $[6,47]$ which stated that grain yield increased with an increase in N \& P rates. On top of that, Khan et al. [17] also reported that grain yield was highly affected by the interaction effect of variety by NP fertilizer rates. Application of the highest fertilizer combination when there is an adequate rainfall like in the cropping season had a positive effect on growth and yield-related traits. Raw data indicated in the second cropping season that higher yieldrelated traits were recorded. Amazingly, the highest grain yield that was produced in the first growing season was less than the lowest grain yield which was produced in the second growing season. The grain yield produced in the second growing season was increased by $59.8 \%$ as compared to the first growing season. This is basically due to the presence of an ample amount and regular rainfall distribution throughout the second cropping season as compared to the first cropping season. In general, both varieties and fertilizer treatments gave by far better grain yields in the second cropping season as compared to the first growing season. In addition, Baate variety performed well in almost all parameters. This is mainly due to the existence of genetic variation between two maize varieties. Many findings reported that maize is very sensitive to drought at the flowering stage. This result is supported by Talebi et al. [48] who reported that genetic and inconsistent environmental conditions are the main factors influencing grain yield development. Olusegun [49] also affirmed that grain yield was highly affected by the interaction of $\mathrm{P}$ and $\mathrm{N}$. Belay and Adare [9] reported that the maximum grain yield was obtained from hybrid maize variety of BHQPY 545 in plots treated with $150 \mathrm{~kg}$ NPS with $87 \mathrm{~kg} \mathrm{~N} \mathrm{ha}^{-1}$. Dagne [10] also affirmed that higher grain yield of maize was found from blended NPS as compared to NP application.

3.3.7. Harvest Index (\%). The harvest index of a crop is an interaction of its physiological efficiency and its ability to convert the photosynthetic material into economic yield. Interaction of variety by NPS and N had a significant effect on harvest index in both seasons. As indicated in Table 11, the application of $100 \mathrm{~kg}$ NPS and $87 \mathrm{~kg} \mathrm{~N} \mathrm{ha}^{-1}$, as well as 100 with $130.5 \mathrm{ha}^{-1}$ to Melkasa 2, gave the maximum harvest indices (43\%). The presence of lower
TABLE 11: Harvest index as affected by three-way interaction of variety, NPS, and $\mathrm{N}$ in both seasons.

\begin{tabular}{|c|c|c|c|c|}
\hline \multirow[b]{2}{*}{ Variety } & \multicolumn{2}{|l|}{ Treatments } & \multicolumn{2}{|c|}{$\begin{array}{c}\text { Harvest index } \\
(\%)\end{array}$} \\
\hline & NPS rate $\left(\mathrm{kg} \mathrm{ha}^{-1}\right)$ & $\mathrm{N}$ rate $\left(\mathrm{kg} \mathrm{ha}^{-1}\right)$ & 2018 & 2019 \\
\hline \multirow{9}{*}{ Baate } & \multirow{3}{*}{50} & 43.5 & $35^{\text {abcde }}$ & $43^{\mathrm{bcd}}$ \\
\hline & & 87 & $33^{\text {bcde }}$ & $43^{\mathrm{bcd}}$ \\
\hline & & 130.5 & $34^{\text {abcde }}$ & $45^{\mathrm{bcd}}$ \\
\hline & \multirow{4}{*}{100} & 43.5 & $37^{\text {abcde }}$ & $45^{\mathrm{bcd}}$ \\
\hline & & 87 & $31^{\text {cde }}$ & $41^{\text {cde }}$ \\
\hline & & 130.5 & $29^{\mathrm{e}}$ & $47^{\mathrm{abcd}}$ \\
\hline & & 43.5 & $32^{\text {cde }}$ & $32^{\mathrm{e}}$ \\
\hline & \multirow[t]{3}{*}{150} & 87 & $28^{\mathrm{e}}$ & $40^{\text {cde }}$ \\
\hline & & 130.5 & $30^{\mathrm{de}}$ & $54^{\mathrm{a}}$ \\
\hline \multirow{9}{*}{ Melkasa 2} & & 43.5 & $42^{\mathrm{ab}}$ & $41^{\text {cde }}$ \\
\hline & \multirow[t]{3}{*}{50} & 87 & $42^{\mathrm{ab}}$ & $50^{\mathrm{ab}}$ \\
\hline & & 130.5 & $39^{\mathrm{abcd}}$ & $42^{\mathrm{bcd}}$ \\
\hline & & 43.5 & $39^{\mathrm{abcd}}$ & $43^{\mathrm{bcd}}$ \\
\hline & \multirow[t]{3}{*}{100} & 87 & $43^{\mathrm{a}}$ & $43^{\mathrm{bcd}}$ \\
\hline & & 130.5 & $43^{\mathrm{a}}$ & $48^{\mathrm{abc}}$ \\
\hline & & 43.5 & $41^{\mathrm{abc}}$ & $42^{\mathrm{bcd}}$ \\
\hline & \multirow[t]{2}{*}{150} & 87 & $36^{\text {abcde }}$ & $42^{\mathrm{bcd}}$ \\
\hline & & 130.5 & $39^{\mathrm{abcd}}$ & $39^{\text {de }}$ \\
\hline LSD (0.05) & & & 0.05 & 0.09 \\
\hline CV (\%) & & & 8.6 & 12.3 \\
\hline
\end{tabular}

Means in the columns following the same letter are not statistically significant at the 0.05 probability level. LSD = least significant difference; $\mathrm{CV}=$ coefficient of variation.

biomass yield from Melkasa 2 variety could be due to the presence of low number of leaves per plant, thin stalks, and short plant heights, and having a little bit shorter days to maturity may contribute to a higher harvest index. However, the minimum harvest index $(28 \%)$ was obtained from Baate where plots were treated with 150 NPS with $87 \mathrm{~kg} \mathrm{ha}^{-1}$ in the first cropping season. On the other hand, in the second cropping season, the combined application of $150 \mathrm{~kg}$ NPS and $130.5 \mathrm{~kg} \mathrm{~N} \mathrm{ha}^{-1}$ to Baate variety gave the highest harvest index (54\%) whereas the lowest harvest index (32\%) was found from the application of $150 \mathrm{~kg}$ NPS and $43.5 \mathrm{~kg} \mathrm{~N}$ in the same variety. This could be when plants got ample growth resources, plants may have more leaves and chlorophyll that help to trap more sunlight and undertake more photosynthesis, and then, more carbohydrates go to the reproductive parts. Similarly, Alias et al. [37] showed that higher harvest index was found from variety Golden and from the highest NP level $\left(150 \times 100 \mathrm{~kg} \mathrm{ha}^{-1}\right)$. Abera et al. [32] also stated that harvest index was significantly affected by variety and $\mathrm{N}$ level. As it was observed from their mean values, almost both varieties produced higher harvest indices in the second cropping season as compared to the first cropping season. This is probably due to the presence of adequate rainfall in the second cropping season, and plants were matured at the right time without enforcing by the external factor; therefore, more photosynthetic carbohydrates could be translocated from the source to the sink/grain/economic part/rather than vegetative parts that may be attributed having higher grain yields and harvest indices. 
3.4. Partial Budget Analysis. This economic analysis is done based on the average yield of each treatment across all repetitions [50]. Therefore, the estimates of the net benefits for 18 treatments in both seasons indicated that Baate variety gave the highest net benefit (664.6 USD) with the highest marginal rate of return (934.4\%) where plots were fertilized with $150 \mathrm{~kg}$ NPS and $87 \mathrm{~kg} \mathrm{~N}^{-1}$ in the first cropping season. On the other hand, the application of $150 \mathrm{~kg}$ NPS and $130.5 \mathrm{~kg} \mathrm{~N}$ to Baate variety gave the highest net benefit $(2,033.4$ USD) with the highest marginal rate of return $(3106.9 \%)$ in the second cropping season which is by far better as compared to the first cropping season. This is probably due to the presence of an ample amount of rainfall and regular rainfall distribution in the 2019 cropping season.

\section{Conclusions}

Recently, removal of crop residue on cultivated land and continuous cultivation causes a deficit of some secondary and micronutrients that have not been seen so far in some Ethiopian soils. Based on this, some blended fertilizers like NPS fertilizer are introduced in place of DAP very recently to address particularly sulfur deficit in the study area. Therefore, the study was conducted to provide concrete information to the farmers about the effect of newly introduced blended NPS on the production and productivity of maize. The research results showed that the leaf area index, thousand kernel weight, biomass yield, grain yield, and harvest index were significantly affected by the interaction of variety, NPS, and N in 2018. Similarly, the interaction effect of variety, NPS, and $\mathrm{N}$ had also a significant effect on grain yield and harvest index in 2019. Almost all parameters were affected by the main effect variety in both seasons. The maximum growth parameters and yield components were recorded from Baate and $150 \mathrm{~kg}$ blended NPS. Besides, the highest grain yield $(9.7 \mathrm{t}$ $\mathrm{ha}^{-1}$ ) was produced from Baate at a combined application of $150 \mathrm{~kg}$ NPS and $130.5 \mathrm{~kg} \mathrm{~N} \mathrm{ha}{ }^{-1}$. The partial budget analysis also confirmed that the highest net benefit $(2,033.4$ USD) with the highest marginal rate of return $(3106.9 \%)$ was obtained at Baate variety where plants were fertilized with $150 \mathrm{~kg}$ NPS and $130.5 \mathrm{~kg} \mathrm{~N} \mathrm{ha}{ }^{-1}$. In conclusion, an integrated application of $150 \mathrm{~kg} \mathrm{NPS}+130.5 \mathrm{~kg} \mathrm{~N}^{-1}$ to Baate variety is agronomically optimum and economically realistic fertilizer level to get a higher grain yield in the study area.

\section{Data Availability}

Entire agronomic data taken from the experiment and reported in the manuscript are incorporated in the article. Furthermore, datasets are available from the corresponding author upon request.

\section{Conflicts of Interest}

The author declares no financial and nonfinancial conflicts of interest regarding the publication of this article.

\section{Acknowledgments}

The author acknowledged Haramaya University for providing different experimental facilities and technical assistants who supported during field management and follow-ups as well as data collection.

\section{References}

[1] B. Stephanie and C. Brown, Field Crop Manual of Maize, Cambodian Agricultural Research and Development Institute of Department of Primary Industries, Phnom Penh, Cambodia, 1st edition, 2008.

[2] T. Wondesen and B. Sheleme, "Identification of growth limiting nutrients in alfisols: soil physico-chemical properties, nutrient concentrations and biomass yield of maize," American Journal of Plant Nutrition, vol. 1, pp. 23-35, 2011.

[3] R. O. Onasanya, O. P. Aiyelari, A. Onasanya, S. Oikeh, F. E. Nwilene, and O. O. Oyelakin, "Growth and yield response of maize (Zea mays L.) to different rates of nitrogen and phosphorus fertilizers in southern Nigeria," World Journal of Agricultural Sciences, vol. 5, no. 4, pp. 400-407, 2009.

[4] CSA (Central Statistical Authority), Agricultural Sample Survey. Report on Area and Production of Major Crops. 532 Statistical Bulletin, Vol. 1, CSA, Addis Ababa, Ethiopia, 2018.

[5] G. Tadila, "Effect of manure and nitrogen rates on yield and yield components of garlic (Allium sativum L.) at Haramaya, easter Ethiopia," M.Sc. thesis, Haramaya University, Haramaya, Ethiopia, 2011.

[6] M. Tekalign, T. Erkossa, and B. Tulema, "Soil fertility and plant nutrition research on Tef in Ethiopia," in Proceedings of the International Workshop on Tef Genetics and Improvement, Addis Ababa, Ethiopia, October 2000.

[7] E. G. Besufikad and T. Dugasa, "Response of maize yield and yield related components to different levels of nitrogen and phosphorus fertilizers," Acta Scientific Agriculture, vol. 3, no. 1, pp. 3-8, 2018.

[8] EthioSIS (Ethiopia Soil Information System), Soil Fertility Status and Fertilizer Recommendation Atlas for Tigray Regional State, Ethiopia, EthioSIS, Addis Ababa, Ethiopia, 2014.

[9] M. Belay and K. Adare, "Response of growth, yield components, and yield of hybrid maize (Zea mays L.) varieties to newly introduced blended NPS and N fertilizer rates at Haramaya, eastern Ethiopia," Cogent Food and Agriculture, vol. 6, no. 1, pp. 1-15, 2020.

[10] C. Dagne, "Blended fertilizers effects on maize yield and yield components of western Oromia, Ethiopia," Agriculture, Forestry and Fisheries, vol. 5, no. 5, pp. 151-162, 2016.

[11] Z. Bekeko, "Effect of nitrogen and phosphorus fertilizers on some soil properties and grain yield of maize (BH-140) at Chiro, western Hararghe, Ethiopia," African Journal of Agricultural Research, vol. 8, no. 45, pp. 5693-5698, 2013.

[12] M. Kebede, T. Balemi, T. Abera, G. Hailu, G. Gurmu, and F. Getaneh, "Some maize agronomic practices in Ethiopia, a review of research experiences and lessons from agronomic panel survey in Oromia and Amhara regions," African Journal of Agricultural Research, vol. 14, no. 33, pp. 1749-1763, 2019.

[13] A. Qahar and B. Ahmad, "Effect of nitrogen and sulfur on maize hybrids yield and post-harvest soil nitrogen and sulfur," Sarhad Journal of Agriculture, vol. 32, no. 3, pp. 239-251, 2016.

[14] A. Rafiq, D. Khadim, I. Jasim, and W. Sara, "Effect of sulfur on nitrogen use efficiency and yield of maize crop," Advances in Environmental Biology, vol. 10, no. 11, p. 85, 2016. 
[15] N. Ahmad, M. Rashid, and A. G. Vaes, Fertilizers and Their Uses in Pakistan, NFDC, Islamabad, Pakistan, 1996.

[16] T. Khaliq, T. Mahmood, J. Kamal, and A. Masood, "Effectiveness of farmyard manure, poultry manure and nitrogen for corn (Zea mays L.) productivity," International Journal of Agriculture and Biology, vol. 2, pp. 260-263, 2004.

[17] F. Khan, S. Khan, S. Fahad et al., "Effect of different levels of nitrogen and phosphorus on the phenology and yield of maize varieties," American Journal of Plant Sciences, vol. 05, no. 17, pp. 2582-2590, 2014.

[18] MoA (Ministry of Agriculture), Animal and Plant Health Regulatory Directorate, MoA, Addis Ababa, Ethiopia, 2010.

[19] CIMMYT (Centro Internacional de Mejoramiento de Maiz y Trigo/International Maize and Wheat Improvement Center), Managing Trials and Reporting Data for CIMMYT's International Maize Testing Program, CIMMYT, Texcoco, Mexico, 1985.

[20] VSN International, GenStat for Windows, VSN International, London, UK, 2012, http://genstat.co.uk/, 15th edition.

[21] K. A. Gomez and A. A. Gomez, Statistical Procedures for Agricultural Research, John Wiley \& Sons, New York, NY, USA, 2nd edition, 1984.

[22] CIMMYT (Centro Internacional de Mejoramiento de Maiz y Trigo/International Maize and Wheat Improvement Center), From Agronomic Data to Farmer Recommendations. An Economic Work Book. Mexico, CIMMYT, Texcoco, Mexico, 1988.

[23] H. F. Murphy, A Report on Fertility Status and Other Data on Some Soils of Ethiopia, Haramaya University College of Agriculture, Dire Dawa, Ethiopia, 1968.

[24] T. Tekalign, Soil, Plant, Water Fertilizer, Animal Manure and Compost Analysis Manual, Working Document, International Livestock Center for Africa, Addis Ababa, Ethiopia, 1991.

[25] A. Cottenie, Soil and Plant Testing as a Basis of Fertilizer recommendations, FAO Soil Bulletin 38/2, Food and Agriculture Organization of the United Nations, Rome, Italy, 1980.

[26] P. Hazelton and B. Murphy, Interpreting Soil Test Results: What Do All the Numbers Mean?, CSIRO Publishing, Collingwood, Australia, 2nd edition, 2007.

[27] S. Rao, K. K. Singh, and M. Ali, "Sulfur: a key nutrient for higher pulse production," Fertiliser News, vol. 46, no. 10, pp. 37-50, 2001.

[28] T. Geremew, "Effects of nitrogen and phosphorus fertilizers on the growth, yield and yield components of maize (Zea mays L.) at Nedjo, west Wollega, Ethiopia," M.Sc. thesis, Haramaya University, Dire Dawa, Ethiopia, 2009.

[29] G. Sisay and M. Adugnaw, "Effect of combined application of NPS fertilizer and compost on phenology and growth of quality protein maize (Zea mays L.) at Jimma, south western Ethiopia," International Journal of Research Studies in Science, Engineering and Technology, vol. 7, pp. 18-28, 2020.

[30] R. S. Sharifi and R. Taghizadeh, "Response of maize (Zea mays L.) cultivars to different levels of nitrogen fertilizer," Journal of Food, Agriculture \& Environment, vol. 7, no. 3-4, pp. 518-521, 2009.

[31] M. J. Yusuf, U. T. Musa, and A. O. Ifeoluwa, "Evaluation of maize varieties under varying fertilizer application rates in Owode-Egba area of Ogun state Nigeria," Journal of Agriculture and Veterinary Science, vol. 12, pp. 25-32, 2019.

[32] T. Abera, T. Debele, and D. Wegary, "Effects of varieties and nitrogen fertilizer on yield and yield components of maize on farmers field in mid altitude areas of western Ethiopia,"
International Journal of Agronomy, vol. 2017, Article ID 42539, 13 pages, 2017.

[33] A. Hamidi and A. D. M. Nasab, "The effect of various plant density and nitrogen use levels on phenology of two mediummaturity corn (Zea mays L.) hybrids," Iranian Journal of Agricultural Sciences, vol. 32, no. 4, pp. 857-874, 2001.

[34] T. Khaliq, A. Ali, Z. Iqbal, S. W. Hassan, M. Yasin, and S. Ahmad, "Effect of nitrogen and sulphur on phenology, growth and yield parameters of maize crop," Science International (Lahore), vol. 25, no. 2, pp. 363-366, 2013.

[35] S. Ahmad, A. A. Khan, M. Kamran, I. Ahmad, S. Ali, and S. Fahad, "Response of maize cultivars to various nitrogen levels," European Journal of Experimental Biology, vol. 8, no. 1-2, pp. 1-5, 2018.

[36] F. B. Anjorin and D. J. Ogunniyan, "Comparison of growth and yield components of five quality protein maize varieties," International Journal of Agriculture and Forestry, vol. 4, no. 1, pp. 1-5, 2014.

[37] S. A. Toor, "Effect of NPK application on the growth and yield of new maize genotypes planted in two geometrical pattern," M.Sc. thesis, Department of Agronomy; University of Agriculture, Faisalabad, Pakistan, 1990.

[38] A. Alias, M. Usman, E. Ullah, and E. A. Warraich, "Effect of different phosphorus levels on the growth and yield of two cultivars of maize," International Journal of Agriculture and Biology, vol. 4, pp. 632-634, 2003.

[39] L. Hejazi and A. Soleyman, "Effect of different amounts of nitrogen fertilizer on grain yield of forage corn cultivars in Isfahan," International Journal of Advanced Biological and Biomedical Research, vol. 3, pp. 608-614, 2014.

[40] T. Abera and A. Adinew, "Effect of blended NPS fertilizer supplemented with nitrogen on yield components and yield of maize (Zea mays L.) in Kachabirra district, Kembata Tambaro zone, southern Ethiopia," International Journal of Research in Agricultural Sciences, vol. 7, pp. 2348-3997, 2020.

[41] M. K. Fareed, "Effect of varying fertilizer rate and plant stand density on growth and yield of spring maize," M.Sc. thesis, Department of Agronomy, University of Agriculture, Faisalabad, Pakistan, 1996.

[42] N. Hussain, A. Z. Khan, H. Akbar, and S. Akhtar, "Growth factors and yield of maize as influenced by phosphorus and potash fertilization," Sarhad Journal of Agriculture, vol. 22, no. 4, pp. 579-583, 2006.

[43] M. M. Jaliya, A. Ibrahim, A. B. Babaji, B. M. Sani, and D. Aminu, "Effects of nitrogen and sulfur fertilizers on maize grain protein content of QPM maize varieties at Samaru zaria," Crop and Environment, vol. 2, no. 1, pp. 132-134, 2013.

[44] M. Maqsood, R. Ali, N. Nawaz, and N. Yousaf, "The effect of NPK application in different proportions on the growth and yield of spring maize," Pakistan Journal of Biological Sciences, vol. 3, no. 2, pp. 356-357, 2000.

[45] J. Bakht, S. Ahmad, M. Tariq, H. Akber, and M. Shafi, "Response of maize to planting methods and fertilizer N," Journal of Agricultural and Biological Science, vol. 1, pp. 8-14, 2006.

[46] S. K. Khalil, M. S. Afridi, and M. Iqbal, "Plant height, weeds weight and hay yield of maize and mungbean in mono and associated culture as affected by NPK application," Sarhad Journal of Agriculture, vol. 4, pp. 377-385, 1988.

[47] Z. H. Khan, S. Iqbal, A. Iqbal, N. Akbar, and D. L. Jones, "Response of maize (Zea mays L.) varieties to different levels of nitrogen," Crop and Environment, vol. 2, pp. 15-19, 2011.

[48] R. Talebi, F. Fayaz, and N. A. Jelodar, "Correlation and path coefficient analysis of yield and yield components of chickpea (Cicer arietinum L.) under dry land condition in the west of 
Iran,” Asian Journal of Plant Sciences, vol. 6, pp. 1151-1154, 2007.

[49] O. S. Olusegun, "Nitrogen (N) and phosphorus (P) fertilizer application on maize (Zea mays L.) growth and yield at AdoEkiti, south-west, Nigeria," American Journal of Experimental Agriculture, vol. 6, no. 1, pp. 22-29, 2014.

[50] B. Duncan, C. Eric, K. Mark, and H. Bruno, Economic Analysis of on Farm Trials, A Review of Approaches and Omplications for Research Program Design, Michigan State University, East Lansing, MI, USA, 1990. 